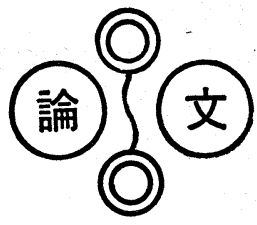

\section{石炭液化反応における触媒の役割}

\author{
-1983. 1. 28 受理一
}

化学技術研究所三木康 朗*, 杉本義一

\section{1，緒言}

石炭を液化して石油代替燃料を合成するプロセスは 熱分解反応を基本とするが，触媒を使用することによ り液化率の増大, 生成油の軽質化などを図ることがで きる。使用される触媒種は多岐にわたるが I G 法 ${ }^{122}$, 新 IG 法 ${ }^{3}$ V代表される鉄打よびスズ系触媒, H-Coal 法4) 8), Synthoil 法9) 12)，Dow 法131 リブデンまたはタングステンを主成分とする石油留分 の水素化精製用触媒拉よび塩化亜鉛, 塩化スズなどの 金属八ログン化物の三つのグループに大別できる ${ }^{14)}$

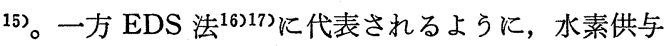
性の高い溶媒を用いることにより無触媒下でも高い液 化率を得ることが可能であり, 触媒を用いることの効 果の多角的な解析が望まれている。

石炭液化に抢ける石油精製用触媒と鉄系触媒の比較

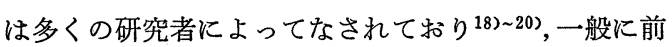
者を使用した場合に高い液化率が得られているが，両 系の触媒の特徵については十分には明らかにされてい ない。ここではそれらの触媒系の働さの特徴を明らか にする目的で，鉄系触媒として焼成掠よび硫化処理し たヘマタイト抢よび赤泥を選び，石油精製用触媒とし て 6 種類の市販触媒を選んで液化率, 液化油の各留分 の収率叔よび性状を比較した。

\section{2. 実験}

\section{1 石炭捛よび触媒}

反応に用いた石炭は太平洋炭で，その組成は水分 $4.2 \%$, 灰分 $17.1 \%$, 揮発分 $44.5 \%$, 固定炭素 $38.4 \%$, 全硫黄 $0.4 \%$, 炭素 $76.2 \%$, 水素 $6.6 \%$, 窒素 $1.9 \%$, 酸素14.9\%(diff.)であった。

触媒に用いたへマタイトは微粉末状の市販品を, 赤 泥は昭和電工秼より提供を受けた粉末を純水で十分洗 浄したものを，それぞれ焼成あるいは硫化処理して用

化学技術研究所 茨城県筑波郡谷田部町

* 現 新エネルギー総合開発機構 東京都豊島区東池袋
いた。石油精製用触媒としては, Ketjen-124, Ketjen153, HC-5, H-Coal, Shell-324 括よび HDS-20 Trilobe 触媒を硫化処理して用いた。

焼成処理は空気気流中 $450^{\circ} \mathrm{C}$ で12時間加熱して行い， 硫化処理は焼成処理をした後さらに水素気流中, “常圧 下, $450^{\circ} \mathrm{C}$ で 5 時間還元したのち $10 \% \mathrm{H}_{2} \mathrm{~S}-\mathrm{H}_{2}$ 混合ガス で $450^{\circ} \mathrm{C}, 2$ 時間反応することにより行った。

\section{2 反応装置扣よび実験操作法}

内容積 $500 \mathrm{~m} \ell の$ 電磁誘導回転攪拌式オートクレーブ に石炭 $80 \mathrm{~g}(\mathrm{maf})$ ，テトラリン $100 \mathrm{~g}$, 触媒 $10 \mathrm{~g}$ を充て 几し, 水素初圧 $70 \mathrm{~kg} / \mathrm{cm}^{2}$ で $400^{\circ} \mathrm{C}$ まで昇温し, さらに水 素を加光て全圧力を $220 \mathrm{~kg} / \mathrm{cm}^{2}$ にし，その温度で 2 時間 反応させた。反応中は二次圧調整器によって水素を連 続的に補給することにより，全圧力を一定に保った。 反応後液状生成物および触媒を含む固体物質はピペッ トとさじを用いてオートクレーブより取り出し，秤量 後常圧蒸留拈よび減圧蒸留 $\left(20 \mathrm{mmHg}, 260^{\circ} \mathrm{C}\right)$ により 留出油を得た。この留出油の重量から溶媒に用いたテ トラリンの重量 $(100 \mathrm{~g})$ および蒸留の際に得られた水 の重量を減算して, 石炭からの留出油の収量とした。 蒸留残渣はソックスレ一抽出器を用いてオイル(ヘプ タン可溶), アスファルテン(トルェン可溶でヘプタン 不溶) 扎よびトルエン不溶分（触媒上の吸着炭化水素 拉よび吸着水を含む）に分別した。なお，オートクレ ーブの壁に付着した液状成分はティッシュペーパーを 用いて回収した。その重量増加分は，すでに回収され た液状成分の分析結果にしたがって, 留出油, オイル およびアスファルテンに加光た。

水素の吸収量は, 反応温度到達後二次圧調整器を通 って流入した水素量と, 反応終了後のガス状成分の分 析値より求めた。各留分の収率は, (各留分の重量/ $80 \mathrm{~g}) \times 100 \%$ で表わし, 液化率は（100-トルエン不溶 分の収率）で定義した。loss は主として生成物回収中 に散逸した軽質留分およびオートクレーブ本体に付属 する配管内に付着した留分である。 
Table 1 Effect of added catalyst on product distribution

\begin{tabular}{|c|c|c|c|c|c|c|c|c|}
\hline \multirow[b]{2}{*}{ Catalyst } & \multirow[b]{2}{*}{$\begin{array}{l}\text { Pre- } \\
\text { treatment }\end{array}$} & \multicolumn{7}{|c|}{$\mathrm{H}_{2}$ Addition and product distribution (wt $\%$, MAF Coal) } \\
\hline & & $\begin{array}{c}\mathrm{H}_{2} \\
\text { Addition }\end{array}$ & $\begin{array}{l}\text { Gaseous } \\
\text { product*1 }\end{array}$ & Distillate & Oil & $\begin{array}{l}\text { Asphal- } \\
\text { tene }\end{array}$ & $\begin{array}{l}\text { Toluene } \\
\text { insoluble }\end{array}$ & Others*2 \\
\hline \multicolumn{2}{|l|}{ None } & 0.2 & 5.6 & 15.1 & 26.0 & 19. 3 & 13.9 & 20.5 \\
\hline 1) Hematite & Calcined & 0.6 & 6.2 & 11.9 & 28.1 & 21.4 & 7.8 & 25.3 \\
\hline 2) Hematite & Sulfided & 1.4 & 6.0 & 11.8 & 29.5 & 19.8 & 0.4 & 33.9 \\
\hline 1) Red mud & Calcined & 0.6 & 6.4 & 16.1 & 27.6 & 19.1 & 7.1 & 24.3 \\
\hline 2) Red mud & Sulfided & 1.2 & 5.8 & 18.1 & 35.5 & 21.0 & 1.4 & 19.6 \\
\hline 3) NWSA*3 & Sulfided & 1.4 & 5.9 & 20.3 & 38.0 & 14.0 & 2.5 & 20.5 \\
\hline 4) $\mathrm{NMA}^{* 4}(\mathrm{~A})$ & Sulfided & 1.6 & 5.6 & 20.0 & 41.8 & 1.8 & 3.3 & 29.0 \\
\hline 4) $\mathrm{NMA}(\mathrm{B})$ & Sulfided & 1.4 & 5.6 & 17.1 & 40.8 & 8.0 & 2.5 & 27.8 \\
\hline 4) $\mathrm{CMA}^{* 5}(\mathrm{~A})$ & Sulfided & 1.4 & 5.8 & 14.4 & 37.6 & 7.6 & 4.0 & 32.2 \\
\hline 4) $\mathrm{CMA}(\mathrm{B})$ & Sulfided & 1.4 & 6.0 & 12.9 & 38.8 & 5.8 & 2.9 & 35.2 \\
\hline 4) $\mathrm{CMA}(\mathrm{C})$ & Sulfided & 1.4 & 5.8 & 12.5 & 39.3 & 9.9 & 3.1 & 31.2 \\
\hline \multirow{2}{*}{\multicolumn{2}{|c|}{$*_{1} \mathrm{CH}_{4}, \mathrm{C}_{2} \mathrm{H}_{6}, \mathrm{CO}, \mathrm{CO}_{2}$}} & \multicolumn{3}{|c|}{$\mathrm{NiO}-\mathrm{WO}_{3}-\mathrm{SiO}_{2}-\mathrm{Al}_{2} \mathrm{O}_{3}$} & \multirow{2}{*}{\multicolumn{3}{|c|}{$\mathrm{CoO}-\mathrm{MoO}_{3}-\mathrm{Al}_{2} \mathrm{O}_{3}$}} & \\
\hline & & $*_{4} \mathrm{~N}$ & $\mathrm{iO}-\mathrm{MoO}_{3}-\mathrm{A}$ & & & & & \\
\hline
\end{tabular}

\section{3 分析方法}

留出油の組成は S P-2100溶融シリカ毛管カラム $(50$ $\mathrm{m} \times 0.2 \mathrm{~mm}$ ) を備えたガスクロマトグラフ (HewlettPackard，5880A）を用いて分析した。詳細は前21222 に記した。蒸留残渣は H/C 值, 硫黄含量および窒素 含量を求めた。 H/C 值の測定には柳本商事侏製元素 分析器（MT-2）を用い, 硫黄含量の分析には LECO 社製燃焼管式自動硫黄分析器（S C-132）を用い，窒 素含量はミクロケルダール法によって測定した。

\section{3. 結果および考察}

各種触媒を用いたときの生成油の分布を Table 1 亿 示した。硫化処理した触媒を用いた場合には, 固状成 分は灰分と触媒しか認められず，トルエン不溶分は触 媒の重量増加として認められた。これは触媒に強く吸 着した炭化水素拉よび水と考兄られ, 液化率はほぼ $100 \%$ に相当する。水素の吸収量は 1 モル $/ 100 \mathrm{~g}$ 石炭 (maf) 以下であり, 圧力計の読みや反応中の室温変化 （蓄圧器の圧力变化）による誤差は \pm 0.2 モ程度と推 定された。

Table 1 の生成物分布は触媒によって 異なったが,

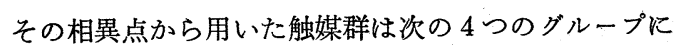
大別された。すなわち, (1)焼成したへマタイトおよび赤 泥触媒, 換言すると焼成した鉄系触媒。この触媒上で は, 液化率はかなり増大するがアスファルテンの分解 が起こりにくい。(2)硫化処理した鉄系触媒。この触媒 上では液化率は著しく増大するが, アスファルテンの 分解は起こりにくい。(3)硫化処理したタングステン系
触媒（ここではニッケルータングステンーシリカーア ルミナ触媒)。この触媒上では液化率は著しく増大し. アスファルテンの分解むかなり促進される。(4)硫化処 理したモりブデン系触媒（コバルトーモリブデンーア ルミナ怙よびニッケルーモリブデンーアルミナ触媒)。 この触媒上では液化率は著しく増大し, アスファルテ ンの分解も著しく促進される。な拈 Table1から，い ずれの触媒を用いてもオイルから留出油への分解は比 較的起こりにくいことが示された。

Table 2 に, Table 1 に示した 各留分の 硫黄含量, 窒素含量怙よび酸素含量（計算值）を示した。硫黄原 子はもともと原料石炭中の含有率が低く, 生成油中の 含有率む低かった。同一の反応の留分を比較すると, アスファルテンの硫黄含有率はオイルの硫黄含有率よ りも高いが，反応が異なるとこの差は明確ではない。 たとえば，鉄系触媒上でのオイルの硫黄含有率は，モ リブデン系触媒上でのアスファルテンの硫黄含有率よ りも高かった。

窒素原子は原料石炭に高濃度で含まれて䏛り, 生成 油中の含有率も高かった。硫黄含有率の場合と異なっ て,オイルの窒素含有率は触媒に依存 ぜずほぼ $1 \%$ で，いずれの反応で生成したアスファルテンの窒素含 有率よりも低かった。

酸素原子の含有率は, 他の元素の分析値から計算に よって求めたため, 他の元素の含有率にくらべて誤差 が大きくなっている。そのため, 触媒間の比較は困難 であるが，全体的に見て触媒間の差は顕著でない。オ 
Table 2 Comparison of the contents of sulfur, nitrogen and oxygen atom

\begin{tabular}{llcccccr}
\hline \multirow{2}{*}{ Catalyst } & \multirow{2}{*}{ Pretreat. } & \multicolumn{2}{c}{ Sulfur $\%$} & \multicolumn{2}{c}{ Nitrogen $\%$} & \multicolumn{2}{c}{ Oxygen $\%$ (calc.) } \\
& & Oil & Asph & Oil & Asph & Oil & Asph \\
\hline None & & 0.09 & 0.14 & 0.97 & 1.87 & 6.0 & 15.0 \\
1) Hematite & Calcined & 0.08 & 0.08 & 1.00 & 1.91 & 3.6 & 12.7 \\
2) Hematite & Sulfided & 0.05 & 0.09 & 1.20 & 1.84 & 4.1 & 8.8 \\
1) Red mud & Calcined & 0.06 & 0.10 & 1.20 & 2.20 & 8.3 & 15.0 \\
2) Red mud & Sulfided & 0.04 & 0.08 & 0.96 & 1.90 & 5.4 & 9.0 \\
3) NWSA & Sulfided & 0.02 & 0.06 & 0.96 & 1.77 & 6.9 & 10.0 \\
4) NMA (A) & Sulfided & 0.02 & 0.03 & 1.02 & 1.50 & 5.0 & 10.0 \\
4) NMA (B) & Sulfidec & 0.01 & 0.03 & 0.74 & 1.40 & 9.7 & 10.6 \\
4) CMA (A) & Sulfided & 0.01 & 0.05 & 1.01 & 1.73 & 4.7 & 10.0 \\
4) CMA (B) & Sulfided & 0.02 & 0.03 & 1.19 & 1.67 & 8.9 & 12.6 \\
4) CMA (C) & Sulfided & 0.01 & 0.03 & 0.95 & 1.31 & 12.1 & 15.6 \\
\hline
\end{tabular}

Table 3 Comparison of $H / C$ value and dehydrogenation of solvent

\begin{tabular}{llccc}
\hline Catalyst & Pretreatment & \multicolumn{2}{c}{ H/C (atomic) } & $\begin{array}{c}\text { Degree of dehydrogenation } \\
\text { of solvent*1 }\end{array}$ \\
\hline None & & 1.15 & 0.90 & 0.45 \\
1) Hematite & Calcined & 1.15 & 0.90 & 0.29 \\
2) Hematite & Sulfided & 1.16 & 0.88 & 0.13 \\
1) Red mud & Calcined & 1.11 & 0.85 & 0.34 \\
2) Red mud & Sulfided & 1.15 & 0.91 & 0.10 \\
3) NWSA & Sulfided & 1.14 & 0.84 & 0.16 \\
4) NMA (A) & Sulfided & 1.16 & 0.81 & 0.18 \\
4) NMA (B) & Sulfided & 1.12 & 0.86 & 0.15 \\
4) CMA (A) & Sulfided & 1.10 & 0.80 & 0.24 \\
4) CMA (B) & Sulfided & 1.24 & 0.84 & 0.23 \\
4) CMA (C) & Sulfided & 1.20 & 0.83 & 0.21 \\
\hline
\end{tabular}

*1 Naphthalene/(Naphthalene+Tetralin) in distillate product

イルの酸素含有率は 5 〜 10\%, アスファルテンの酸素 含有率は10〜15\%であった。

Table 3 に各留分の $\mathrm{H} / \mathrm{C}$ 值を示した。 $\mathrm{H} / \mathrm{C}$ 值は触 媒間の差は比較的小さかったが，オイルとアスファル テンでは明らかに異なっており, 前者で1. 1 1.2, 後 者で0.8〜0.9であった。

以上の結果から，アスファルテンからオイルヘの分 解は，アスファルテンへの水素化反応と，アスファル テン中のヘテロ原子の除去反応，とくに脱酸素と脱公 素反応が主体となっていると考えられる。本実験で用 いた触媒の中で，モリブデン系触媒でアスファルテン の分解率が高かった。この系の触媒上で，脱酸素およ び脱窒素反応が強く促進されると思われる。なお，石

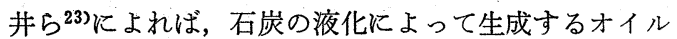

には，石炭の熱分解によって直接生成するものと， ア スファルテンの二次的な分解によって生成するものと があるが，後者の反応が触媒間の活性の差として測定 されたと考觉られる。

Table 1 に示した留出油は, 実際には石炭から生成 した留分と，反応に用いた溶媒との混合物として得ら れた。その組成をガスクロマトグラフで分析したとこ ろ，85 92\%がテトラリンとナフタレンであり（面積 \%), 残りの $1 / 3 \sim 1 / 2$ が直鎖パラフィン類であった。石 炭から直接生成したテトラリン怙よびナフタレンの量 は，用いた溶媒量にくらべて非常に少ないと考え，溶 媒の脱水素率を，反応後の留出留分中のナフタレン／ (テトラリン+ナフタレン) の值として, Table 3 に同 時に示した。Table 3 から，溶媒の脱水素率の触媒間 
による差は, $(1)>(3) \approx(4)>(2)$ で表わされた。

溶媒の脱水素率は，液化率 $86 \%$ の無触媒反応で $45 \%$ であり，この実験条件下では石炭の熱分解で，溶媒か らこの程度の水素原子が引き抜かれると考えられる。 触媒存在下では, 液化率が増大するにあかかわらず, 溶媒の脱水素率は, 無触媒のときに比べて減少した。 石炭液化の初期反応は熱分解反応であると一般に考え られている。触媒が存在しても, 溶媒から石炭への水 素移行は同じように起こるとすると, 触媒の存在によ る溶媒の脱水素率の減少は, 触媒の動きによって, 気 相の水素分子が溶媒へ付加した結果と考えられる。そ の場合には, 溶媒への水素化活性の 触媒間の比較は $(2)>(3) \approx(4)>(1)$ で表わされ，アスファルテンの分解反 応の場合とは逆に, 硫化処理した鉄系触媒はモリブデ ン系触媒よりも高い活性を有することになる。

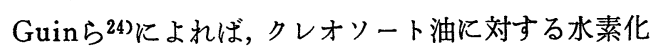
能は硫化した鉄系触媒よりもコバルトーモリブデンー アルミナ触媒の方がすぐれている。しかし本実験では 溶媒の他に石炭, あるいは石炭から生成したアスファ ルテンなどの重質留分が存在するので, 溶媒を単独で 水素化する場合とは状況が異なると考えられる。固体 酸触媒上でデカンの分解がデカリンの添加によって抑 制され ${ }^{25)}$ ， ヘキサデカンの分解が芳香族の添加によっ て抑制される26)など吸着力のより強い化合物の共存に より反応が阻害される例が報告されている。

以上の結果から鉄系触媒とモリブデン系触媒の触媒 特性の差を考察すると, モリブデン系触媒は水素化と へテロ原子の除去に高い活性を有するが，重質留分に 対する吸着力が強く, 重質留分が共存する場合にはそ れが選択的に反応し，一方鉄系触媒は水素化拉よびへ テロ原子の除去に対する活性はモリブデン系触媒に劣 るが重質留分に対する吸着力は比較的弱く，溶媒など の軽い留分の水素化も進行すると考えられた。

モリブデン系触媒とタングステン系触媒の間にも同 様な関係が存在すると考えられる。アルミナなど同一 の担体に担持した両系の触媒の水素化分解活性を比較

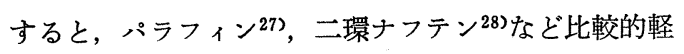
質な化合物の反応に対してはタングステン系触媒の方 が活性が高いが，常圧残油年の反応に対してはモリブ デン系触媒の方が高活性である。両触媒系で, 重質留 分に対する吸着はタングステン系触媒の方が強く, へ テロ原子に対する反応性はモリブデン系触媒の方が大 きいことがその触媒特性になっていると考えられる。

\section{4. 結言}

焼成した鉄系触媒，硫化処理した鉄系触媒およびモ
リブデン系触媒の存在下拉よび無触媒下で, テトラリ ンを溶媒として太平洋炭の液化試験を行い，各触媒の 特徴として次の結果を得た。

焼成した鉄系触媒を用いると液化率はかなり増大す るがアスファルテンの分解は起こりにくい。

硫化した鉄系触媒を用いると液化率は著しく増大す るがアスファルテンの分解は起こりにくい。

硫化したモリブデン系触媒を用いると液化率は著し く増大し, アスファルテンの分解も著しく増大され た。

硫化した鉄系触媒を用いた場合には，モリブデン系 触媒を用いた場合よりも，溶媒の脱水素率が低かっ た。脱水素した溶媒の再水素化が，鉄系触媒上で容易 に起こる結果であると考察した。

\section{文献}

1) Lowry, H.H. "Chemistry of Coal Utilization" Vol.2, Chapter 38 (1945) ; Supplement, Chapter 22, John Wiley (1962)

2）森川 清，本田英昌監修，石炭資源開発・液化技 術（サイエンスフォーラム） p.343 (1981)

3) ibid., p. 353

4) Johanson, E. S., Schuman, S.C., Stotler, H. H. and Wolk, R. H., U.S. Pat. 3,529, 533, July 7 (1970)

5) Johnson, C. A., 8th World Petrol. Cong. Proceedings, 4, 55, Elsevier (1971)

6) Johanson, E. S., U.S. Pat. 3, 769, 198, October 30 (1973)

7) Johnson, C. A., Chervenak, M.C., Johanson, E. S., Stotler, H. H., Winter, Olaf and Wolk, R.H., paper presented at IGT Clean Fuels from Coal Symp., Chicago, September 10-14 (1973)

8) Eccles, R.M. and DeVaux, G. R., Pan-Pacifie Synfuels Conference, Vol. I, C-20, p. 388 (1982)

9) Friedman, S., Yovorsky, P.M. and Aktar, S., Clean Fuels from Coal Symp. Papers, p. 481, IGT (1973)

10) Yovorsky, P.M., Akthar, S. and Friedman, S., AIChE Symp., 70, (137), 101 (1974)

11) Kawa, W., Friedman, W., Frank, W. and Yavorsky, P., Prepr., Am. Chem. Soc., Div. Fuel Chem., 19, (1), 192 (1974) 12) Stanulois, J., Gates, B. and Olson, J., Am. 
Inst. Chem. Eng. J., 22, (3), 577 (1976)

13) Moll, N.G. and Quarderer, G. J., Chem. Eng. Prog., Now., 46 (1974)

14）神谷佳男, 燃協誌, 58, (621), 2 (1979)

15）神谷佳男，燃協誌，61，(667)，968（1982）

16) Furlong, L. E., Effron, E., Vernon, L.W. and Wilson, E. L., Chem. Eng. Progr., 72, (8), 69 (1976)

17) Zaczepinski, S., Brackett, R. H. and Lahn, G. C., Pan-Pacific Synfuels Conference, Vol. I, C-19, p. 372 (1982)

18) Granoff, B., Thomas, M. G., Baca, P.M. and Noles, G. T., Prepr. Am. Chem. Soc. Div. Fuel Chem., 23, (1), 23 (1978)

19) Guin, J.A., Tarrer, A. R., Lee, J.M., van Brakle, H. F. and Curtis, C. W., Ind. Eng. Chem. Proc. Res. Dev., 18, (4), 631 (1979)

20) Sivasubramanian, R. and Crynes, B. L., ibid., 19, 456 (1980)
21）三木康朗，杉本義一，日化，1983，(5)，697

22）三木康朗，杉本義一，日化，1983，(5)，704

23）石井忠雄, 前河涌典, 武谷 愿, 化学工業, 29, 988 (1965)

24) Guin, J.A., Tarrer, A. R., Prather, J. W., Johnson, D. R. and Lee, J. M., Ind. Eng.

Chem. Proc. Des., 17, (2), 118 (1978)

25) Beecher, R., Voorhies, A. Jr. and Elberly, P. Jr., Ind. Eng. Chem. Prod. Res, Dev., 7, 203 (1968)

26) Doane, E. P., Prepr, Am. Chem. Soc. Div. Petr. Chem., 12, (4), B-139 (1967)

27) 三木康朗, 山田谷正子, 大場昌明, 第20回石油学 会研究発表会 (1977)

28）三木康朗, 山田谷正子, 大場昌明, 石油誌, 23, (5), 291 (1980)

29）三木康朗, 山田谷正子, 大場昌明, 杉本義一, 第 11回石油化学討論会 (1981) 


\title{
Role of Catalyst in Hydrogenation of Coal
}

\author{
Yasuo MIKI, Yoshikazu SUGIMoto
}

\author{
(National Chemical Laboratory for Industry)
}

SYNOPSIS :-Coal liquefaction has been performed in the absence and in the presence of catalyst such as iron, tungsten or molybdenum oxides, and the characteristic role of each catalyst in the reaction has been discussed. Taiheiyo-Coal of $80 \mathrm{~g}$, tetralin solvent of $100 \mathrm{~g}$ and catalyst of $10 \mathrm{~g}$ were put into a $500 \mathrm{~m} \ell$ stainless steel autoclave and were heated at $400^{\circ} \mathrm{C}$ for $2 \mathrm{hr}$ under hydrogen pressure. The total pressure was maintained at $220 \mathrm{~kg} / \mathrm{cm}^{2}$ by means of introducing hydrogen gas through a pressure controller during the reaction.

The $86 \%$ of coal was converted in non-catalytic reaction to toluene-soluble materials, while conversion of $93 \%$ was obtained in the reaction with each catalyst of calcined hematite and red mud and conversion of $100 \%$ with each catalyst of sulfided hematite, red mud, nickel-tungsten-alumina, nickel-molybdenum-alumina and cobaltmolybdenum-alumina.

The liquefied product separated into distillate fraction $\left(\sim 410^{\circ} \mathrm{C}\right)$, oil fraction (undistillable and heptane-soluble) and asphaltene fraction (heptane-insoluble and toluene-soluble). The yield and properties of each fraction were significantly depended on the catalyst. In case that either calcined- or sulfided-hematite or red mud catalyst was used, coal conversion increased but the yield of asphaltene was also rather high, which indicates that the secondary cracking of asphaltene produced is difficult to proceed with iron-type catalysts. On the other hand, high value of coal conversion and low yield of asphaltene were obtained with either molybdenum or tungsten catalyst, which indicates that the secondary cracking of asphaltene is promoted on these catalysts. Further cracking of oil fraction to distillate fraction is found to be rather difficult with any of the catalyst used in this study.

The degree of dehydrogenation of solvent was calculated from the value of naphthalene/(naphthalene+tetralin) in the distillate fraction after reaction. The lowest value of it was obtained when sulfided iron-type catalyst was used. The role of catalyst in coal liquefaction has been discussed.

\section{Key Words}

Coal liquefaction, Role of catalyst, Molybdenum catalyst, Iron catalyst 